\title{
Johtotehtäviin liittyvien huolenaiheiden yhteydet urasuunnitelmiin ja työtavoitteisiin korkeasti koulutetuilla asiantuntijoilla
}

\author{
Kiia Kilponen, Anna Takkunen, Heidi Tsupari, Elina Auvinen, \\ Mari Huhtala \& Taru Feldt
}

\begin{abstract}
Worries about leadership among highly educated professionals: Associations with career aspirations and personal work goals.

We investigated how highly educated professionals' worries about leadership roles relate to their career aspirations and personal work goals. Altogether 1151 professionals without leadership positions participated in the survey study. Participants with a high number of leadership-related worries were not planning to pursue leadership positions. Instead, their goals included increasing personal well-being or ending their career. Vice versa, participants with least leadership-related worries strived for career advancement. These findings indicate that worries about leadership should be acknowledged in education and training programs and in career planning, so that worries would not prevent motivated and suitable individuals from seeking leadership positions.
\end{abstract}

Keywords: Worries about leadership, career aspirations, personal work goals

\section{JOHDANTO}

Johtajan roolia on yleensä pidetty haluttuna asemana ja siihen pyrkiminen on nähty tärkeänä uratavoitteena erityisesti korkeasti koulutetuilla henkilöillä. Kaikki eivät kuitenkaan tavoittele pääsyä johtajaksi. Esimerkiksi Yhdysvalloissa toteutetussa kyselytutkimuksessa, johon osallistui 3625 työntekijää, vain 34 prosenttia vastaajista oli kiinnostuneita tavoittelemaan johtoasemaa (Torres 2014). Johtotehtäviin hakeutuminen voi kuitenkin olla monella alalla lähes ainoa vaihto- ehto edetä uralla. Myös Suomessa vähemmistö palkansaajista pitää uralla etenemistä tärkeänä. Vuonna 2013 julkaistun Työolotutkimuksen mukaan $11 \%$ palkansaajista piti uralla etenemistä tärkeimpänä tavoitteena työssään, kun taas omassa työssään kehittymistä tärkeimpänä piti $48 \%$ vastanneista (Sutela \& Lehto 2014). Tarve pätevien henkilöiden saamiseksi johtotehtäviin ei kuitenkaan ole vähentynyt. Johtajalla on keskeinen merkitys organisaation menestyksen kannalta (esimerkiksi yhteisen vision ja tavoitteiden kommunikoimisessa työntekijöille), joten hyvien johtajien löytäminen on organisaatioille tärkeää.

Mutta miksi johtotehtävät eivät houkuttele kaikkia jotka olisivat päteviä tähän asemaan pyrkimään? Yksi syy johtotehtävien välttelyyn voi olla se, että potentiaaliset johtajat ovat huolissaan johtotehtävien mukanaan tuomista kielteisistä seurauksista joko itselleen, läheisilleen tai työyhteisön työntekijöille. Johtotehtäviin liittyvät huolenaiheet ovat uusi, kansainvälisestikin ottaen vasta vähän tutkittu ilmiö (Aycan \& Shelia 2018). Tässä tutkimuksessa tavoitteenamme on tutkia johtotehtäviin liittyviä huolenaiheita suomalaisilla korkeasti koulutetuilla asiantuntijoilla. Selvitämme erityisesti, miten nämä huolenaiheet kytkeytyvät tutkittujen asiantuntijoiden urasuunnitelmiin ja henkilökohtaisiin työtavoitteisiin. Näin saamme tärkeää tietoa siitä, kuinka yleisiä erilaiset johtamiseen liittyvät huolet ovat ja millaisia käytännön yhteyksiä niillä on potentiaalisten tulevien johtajien työurien suunnittelussa.

Tutkimukseen valitut asiantuntijat ovat professoreja, tieteentekijöitä, ekonomeja ja tekniikan akateemisia. Nämä asiantuntijaryhmät ovat kukin omalla tavallaan olennaisia tutkittaessa johtotehtäviin liittyviä huolenaiheita ja niihin yhtey- 
dessä olevia tekijöitä. Professorit ja tieteentekijät ovat tyypillisesti hyvin tutkimus- ja asiantuntijaorientoituneita eivätkä johtotehtävät välttämättä kuulu heidän uratavoitteisiinsa (Nurkkala, 2018). Professorien työnkuvaan liittyy kuitenkin lähes poikkeuksetta hallinnollisia ja tutkimuksellisia johtotehtäviä uran eri vaiheissa (Professoriliitto, 2014). Myös tutkijanuran malliin kuuluu eteneminen vaativampiin tutkimustehtäviin (esim. tenure track -polku), joihin liittyy ajan myötä myös esimies- ja johtotehtäviä (Välimaa, Stenvall, Siekkinen, Pekkola, Kivistö, Kuoppala, Nokkala, Aittola \& Ursin, 2016). Lisäksi tohtoreiden määrän kasvu ja korkeakoulujen säästötoimet ovat johtaneet siihen, että yhä useamman tieteentekijän - niin tutkijoiden kuin opetustyötä tekevienkin - täytyy työllistyä tiedeyhteisön ulkopuolelle (Sainio \& Carver, 2016). Tässä siirtymässä varauksellinen suhtautuminen johtotehtäviin voi kuitenkin olla haasteena työllistymiselle (Haapakorpi, 2008). Ekonomeilla koulutus sisältää johtamiseen liittyviä opintoja pääaineesta riippumatta, ja moni ekonomi joutuukin pohtimaan johtajan roolin houkuttelevuutta jo uransa alkuvaiheessa (Petäjäniemi, 2016). Johtotehtäviin liittyvien huolenaiheiden hallintakeinot ovat näissä pohdinnoissa tarpeen. Lopuksi, nykyisessä työelämässä johtamisen taidot ovat nousseet teknisen osaamisen ohella merkittävään rooliin tekniikan alan ammattilaisten (esim. diplomi-insinöörit) työurissa, vaikka teknisen alan opinnoissa tekninen osaaminen yhä painottuu (Lappalainen, 2012, s. 28-27). Tutkimuksemme tarjoaa ensimmäistä kertaa tietoa siitä, miten näiden alojen edustajat kokevat johtamiseen liittyviä huolia, ja millaisia yhteyksiä huolilla on heidän uratavoitteisiinsa.

\section{Johtotehtäviin liittyvien huolenaiheiden teoreettinen malli}

Johtotehtäviin liittyvillä huolenaiheilla (engl. Worries about Leadership) viitataan niihin huolenaiheisiin, joita työntekijöillä on johtaja-aseman mukanaan tuomia mahdollisia kielteisiä seurauksia kohtaan (Aycan \& Shelia 2018). Aycan ja Shelia (2018) jakavat johtotehtäviin liittyvät huolenaiheet kolmeen ulottuvuuteen, jotka ovat 1) huoli epäonnistumisesta, 2) huoli työn ja muun elämän epätasapainosta sekä 3) huoli vaikeuksista ja ongelmista. Epäonnistumiseen liittyviin huoliin kuuluu muun muassa henkilön huoli siitä, että johtajan roolissa hänen tekemänsä virheet saavat enemmän huomiota. Huoleen työn ja muun elämän epätasapainosta liittyy huoli tuon tasapainon menettämisestä siten, että ystäville, itselle ja perheelle ei riitä työn vuoksi tarpeeksi aikaa. Vaikeuksiin ja ongelmiin liittyvät huolenaiheet puolestaan viittaavat huoleen siitä, että täyttäessään johtajan rooliin liittyviä vaatimuksia henkilö joutuu tuottamaan harmia itselleen tai muille: huolena voi olla esimerkiksi työn aiheuttamat terveysongelmat tai huoli siitä, että joutuu lomauttamaan työntekijöitä.

Aycan ja Shelia (2018) pohjaavat johtamiseen liittyvät huolenaiheiden käsitteen Lazaruksen (1991) kognitiiviseen tunneteoriaan, Decin ja Ryanin (1985) itsemääräämisteoriaan (suom. myös itsemääräytymisteoria ja itseohjautuvuusteoria) sekä Jonesin ja Berglasin (1978) teoriaan itseä vahingoittavasta käyttäytymisestä. Kognitiivisen tunneteorian mukaan ahdistuneisuus perustuu uhkaavien seurauksien ennakoimiseen (Lazarus 1991). Johtotehtäviin liittyen tällaisia uhkaavia seurauksia voivat olla esimerkiksi harmin aiheuttaminen muille, sidosryhmien luottamuksen menettäminen tai työn ja muun elämän tasapainon menettäminen. Decin ja Ryanin (1985) itsemääräämisteoriaan pohjautuen nämä ennakoidut kielteiset seuraukset muodostavat uhan autonomian, kompetenssin ja yhteenkuuluvuuden tarpeiden täyttymiselle. Välttääkseen tämän uhan, ihminen saattaa noudattaa itseään vahingoittavaa strategiaa (Elliot \& Church 2003), joka tarkoittaa tiettyyn rooliin liittyvien toimintojen välttelyä (Jones \& Berglas 1978). Johtotehtäviin liittyvien huolenaiheiden kontekstissa välteltävä rooli on johtajan rooli, joka johtaa käytännön tasolla johtotehtävistä kieltäytymiseen tai sellaisten valintojen tekemiseen, jotka auttavat vähentämään johtotehtäviin ehdolle joutumista.

Johtotehtäviin liittyvien huolenaiheiden kolme ulottuvuutta liittyvät itsemääräämisteorian autonomian, kompetenssin ja yhteenkuuluvuuden perustarpeisiin (Deci \& Ryan 1985). Autonomia tarkoittaa tarvetta vaikuttaa omaan elämään ja toimintaan. Kompetenssi viittaa tarpeeseen kokea itsensä taitavaksi ja osaavaksi. Yhteenkuuluvuus viittaa tarpeeseen olla yhteydessä muihin ihmisiin. Aycanin ja Shelian (2018) mukaan huolet epäonnistumisesta liitty- 
vät kompetenssin tarpeeseen, sillä epäonnistuminen muodostaa uhan yksilön kokemukselle itsestään taitavana ja osaavana. Huolet työn ja muun elämän epätasapainosta puolestaan liittyvät autonomian tarpeeseen, sillä työn ja muun elämän epätasapaino muodostaa uhan yksilön tarpeelle vaikuttaa omaan elämään ja ajankäyttöön. Vaikeuksiin ja ongelmiin liittyvät huolet taas kytkeytyvät yhteenkuuluvuuden tarpeeseen, sillä mahdollinen haitan aiheuttaminen muille voidaan nähdä uhkaavan perustarvetta liittyä muihin ihmisiin (Aycan \& Shelia 2018).

Yllä kuvattu huolenaiheiden käsite on uusi näkökulma johtajuuden tutkimuksessa. Aiemmin johtajaksi hakeutumiseen liittyvää yksilöllistä päätöksentekoa on tutkittu Chanin ja Drasgow'n (2001) esittämän johtamisen motivaation käsitteen avulla. Heidän mukaansa johtamisen motivaatio vaikuttaa henkilön päätökseen ottaa vastaan johtajarooli ja sitoutua siihen sisältyvään vastuuseen sekä yksilön ponnisteluun ja toimintaan tässä roolissa. Aycanin ja Shelian (2018) mukaan johtamisen motivaatio ei kuitenkaan yksin riitä selittämään johtajaksi tulemista. Forgas (1995) on kehittänyt mallin tunnepitoisen informaation vaikutuksesta päätöksentekoon (engl. affect infusion model, AIM), jonka mukaan päätöksentekoon liittyy neljä päätöksentekijän piirrettä: kognitiivinen kapasiteetti, päätöksen merkitys, motivaatio sekä tunteet. Aycan ja Shelia (2018) jatkavat Chanin ja Drasgow'n (2001) aloittamaa tutkimuslinjaa nostamalla AIM-mallin mukaisesti keskiöön päätöksentekoon vaikuttavat tunteet, eli johtotehtäviin liittyvät huolet. Motivaation ohella emootioiden rooli yksilön työuraa koskevassa päätöksenteossa ja urasuunnittelussa on keskeinen: molemmat suuntaavat toimintaa ja ovat todennäköisesti vaikuttamassa yksilön uraa koskeviin valintoihin ja suunnitelmiin. Empiiristä tutkimusta huolenaiheiden yhteyksistä johtotehtäviin hakeutumiseen ei kuitenkaan toistaiseksi ole vielä tehty Aycanin ja Shelian (2018) pioneerityön lisäksi. Tutkimuksemme lisääkin ymmärrystä siitä, millaisia yhteyksiä johtotehtäviin liittyvillä huolenaiheilla voi olla urasuunnitelmiin ja henkilökohtaisiin työtavoitteisiin korkeasti koulutetuilla asiantuntijoilla.

\section{Johtotehtäviin liittyvien huolenaiheiden yhteydet johtotehtäviin liittyviin ura- suunnitelmiin ja henkilökohtaisiin työ- tavoitteisiin}

Urasuunnitelmat kuvaavat henkilön urapolkuun liittyviä aikomuksia ja tavoitteita (Lent \& Brown 1996; Rojewski 2005). Urasuunnitelmien pohjalta työntekijä voi suunnitella toimintaansa yksittäisistä työtehtävistä aina laajempiin työuran suuntaviivoihin, kuten esimerkiksi työn vaativuuteen ja asemaan liittyen (esim. johtotehtävät) (Greenhaus ym. 1995). Yksilön urasuunnitelmien on havaittu ennustavan hänen myöhempiä työhön ja uraan liittyviä valintojaan (Rojewski 2005). Tässä tutkimuksessa kartoitimme korkeasti koulutettujen asiantuntijoiden johtotehtäviin liittyviä urasuunnitelmia selvittämällä strukturoiduilla kysymyksillä, kuinka todennäköisenä he arvioivat johtotehtävät omalla kohdallaan tulevaisuudessa.

Urasuunnitelmiin liittyvät läheisesti myös henkilökohtaiset työtavoitteet, joita on tutkittu sekä persoonallisuuspsykologian (Little 2007; McAdams 1995) että motivaatiopsykologian (Austin \& Vancouver 1996) alueilla. Henkilökohtaiset tavoitteet kuvaavat yksilön käyttäytymistä ohjaavia aikomuksia ja toimintaa tietyn päämäärän saavuttamiseksi (Zimmerman ym. 1992; ks. myös Hyvönen \& Feldt 2017; SalmelaAro \& Nurmi 2017). Tutkiessamme korkeasti koulutettujen asiantuntijoiden henkilökohtaisia työtavoitteita, käytimme avointa kysymystä, johon vastaajat saivat vapaasti kuvata tärkeintä henkilökohtaista työtavoitettaan (ks. Hyvönen ym. 2009; Salmela-Aro \& Nurmi 2017). Näin pystyimme tutkimaan, kuinka suuri osa tutkituista asiantuntijoista asettaa uralla etenemiseen liittyvät tavoitteet tärkeimmäksi tavoitteekseen ja miten he eroavat johtotehtäviin liittyvissä huolenaiheissa muita tavoitteita asettaneista asiantuntijoista.

Aiemmissa tutkimuksissa, joissa työtavoitteiden sisältöjä on kartoitettu vastaavalla avoimella kysymyksellä, on havaittu useita erilaisia tavoiteluokkia. Wiese ja Salmela-Aro (2008) ovat tutkineet 20-65 -vuotiaiden suomalaisten ja saksalaisten eri alojen työntekijöitä, joiden kuvailemat tavoitteet luokiteltiin seuraavaan yhdeksään luokkaan (yleisyysjärjestyksessä): menestys ja korkeamman aseman saavuttami- 
nen, lisäkoulutuksen hankkiminen ja osaamisen kehittäminen, hyvän työn tekeminen, työn varmuus, tyytyväisyys ja positiivinen asenne työtä kohtaan, työhön liittyvät sosiaaliset suhteet, rahaan liittyvät tavoitteet, avoimuus työhön liittyville muutoksille sekä muut työhön liittyvät tavoitteet. Hyvönen kollegoineen luokittelivat alle 35-vuotiaiden suomalaisten esimiesten tärkeimmät työtavoitteet seitsemään luokkaan, joita olivat ammatillinen osaaminen (ammattitaidon kehittäminen) ja uralla eteneminen (korkeamman aseman saavuttaminen, urakehitys), työhyvinvointi (stressinhallinta, työtyytyväisyys, motivaatio), työn vaihto (uuden työn löytäminen tai yrityksen perustaminen), työn jatkuvuus (vakituinen työsuhde, työn varmuus), organisaation menestyminen (työyhteisön tai tiimien menestys ja suoriutuminen) sekä palkkakehitys (palkankorotukset, bonukset) (Hyvönen ym. 2009; Hyvönen ym. 2011; Hyvönen, ym. 2017). Suomalaisilla korkeasti koulutetuilla johtajilla (ikäjakauma 25-68) havaittiin edellisten seitsemän tavoiteluokan lisäksi myös arvostukseen ja vaikuttamiseen sekä työuran päättämiseen liittyviä tavoitteita (Huhtala ym. 2013). Koska tutkimme tässä tutkimuksessa korkeasti koulutettuja asiantuntijoita - kuten Huhtala ym. (2013) - oletamme tutkittujen asiantuntijoiden raportoivan samankaltaisia työtavoitteita. Erityisenä mielenkiinnon kohteena tutkimuksessamme on selvittää, miten johtotehtäviin liittyvät huolenaiheet kytkeytyvät työtavoitteisiin, jotka liittyvät uralla etenemiseen. Näin siksi, että uralla eteneminen merkitsee korkeasti koulutettujen asiantuntijoilla hyvin usein myös vastuullisia esimies- ja johtotehtäviä.

Tutkimme asiantuntijoiden johtotehtäviin liittyvien huolenaiheiden yhteyksiä heidän johtotehtäviin liittyviin urasuunnitelmiinsa Aycanin ja Shelian (2018) teoreettisen mallin oletusten pohjalta. Lazaruksen (1991) kognitiivisen tunneteorian mukaisesti oletamme, että mitä enemmän tutkitut asiantuntijat kokevat johtotehtävien mahdollisiin seurauksiin liittyviä huolenaiheita, sitä todennäköisemmin he arvioivat johtotehtävät omalla kohdallaan uhkana. Itsemääräämisteorian (Deci \& Ryan 1985, 2000) mukaisesti oletamme, että johtotehtäviin liittyvät huolenaiheet uhkaavat yksilön perustarpeita, joita ovat tarve kokea pätevyyttä, yhteenkuulu- vuutta sekä autonomiaa. Esimerkiksi huoli omasta epäonnistumisesta johtotehtävissä uhkaa pätevyyden tunnetta, huoli kasvojen menettämisestä tai muiden vahingoittamisesta uhkaa yhteenkuuluvuutta, ja huoli ajanhallinnan, työn ja muun elämän tasapainon ja yksityisyyden menettämisestä uhkaavat autonomiaa. Perustarpeita uhkaavien tekijöiden välttäminen suuntaa ihmisen motivaatiota, joka taas kytkeytyy siihen, millaisia urasuunnitelmia yksilö tekee ja millaisia henkilökohtaisia työtavoitteita hän itselleen asettaa (Deci \& Ryan 1985, 2000). Lisäksi oletamme itseä vahingoittavan strategian (Elliot \& Church 2003) mukaisesti, että mikäli yksilö ennakoi johtotehtäviin liittyvän kielteisiä seurauksia sekä näkee johtoaseman uhkana perustarpeidensa täyttymiselle, se johtaa todennäköisesti johtajan rooliin liittyvien urasuunnitelmien välttelyyn (Jones \& Berglas 1978). Yhteenvetona toteamme, Aycanin ja Shelian (2018) malliin perustuen, että ne asiantuntijat, joiden tärkein henkilökohtainen työtavoite on uralla eteneminen, kokevat muita tavoitteita asettaneita asiantuntijoita vähemmän johtotehtäviin liittyviä huolenaiheita.

Tutkimuksemme tiivistyy kahteen tutkimuskysymykseen ja niitä koskeviin hypoteeseihin. Koska toiseen tutkimuskysymykseen (tutkimuskysymys 2) liittyy avoimella kysymyksellä mitattava tärkein työtavoite, asetimme teoriaan pohjaten yhden päähypoteesin liittyen uratavoitteisiin.

1. Ovatko johtotehtäviin liittyvät huolenaiheet yhteydessä johtotehtäviin liittyviin urasuunnitelmiin korkeasti koulutetuilla asiantuntijoilla?

H1: Niillä asiantuntijoilla, joilla on enemmän johtotehtäviin liittyviä huolenaiheita, on vähemmän johtotehtäviin liittyviä urasuunnitelmia.

2. Ovatko johtotehtäviin liittyvät huolenaiheet yhteydessä henkilökohtaisiin työtavoitteisiin?

H2: Vähiten johtotehtäviin liittyviä huolenaiheita kuvaavat ne asiantuntijat, joiden tärkein työtavoite liittyy urakehitykseen (esim. johtotehtävä, korkeampi asema). 


\section{MENETELMÄT}

\section{Tutkittavat}

Tutkimus on osa Jyväskylän yliopiston psykologian laitoksen hanketta, jossa tutkitaan johtotehtäviin liittyviä huolenaiheita (ks. Feldt, Tsupari, Kilponen, Auvinen, Huhtala, Muotka, \& Mauno, 2019). Otos poimittiin keväällä 2017 neljän ammattiliiton jäsenrekistereistä: 1) Professoriliitto, 2) Tieteentekijöiden liitto, 3) Tekniikan Akateemiset ja 4) Suomen Ekonomit. Professoriliitossa on noin 3000 jäsentä, joista kysely kohdistettiin kaikille työsuhteessa oleville professorille (ei eläkkeellä oleville), joilla oli jäsenrekisterissä ajantasainen sähköpostiosoite, johon kutsu ja linkki voitiin toimittaa. Kysely lähetettiin yhteensä 1272 jäsenelle. Tieteentekijöiden liiton jäsenistöstä kysely kohdistettiin kaikille työssä oleville tutkijoille ja opettajille (esim. työsuhdenimikkeenä yliopistonlehtori, yliopistontutkija, tutkimusjohtaja, tutkijatohtori, nuorempi tutkija/tutkija, yliopisto-opettaja). Kaikkiaan 3009 tieteentekijälle lähetettiin kysely. Tekniikan Akateemisten liittoon kuuluu noin 70000 jäsentä, jotka ovat etupäässä diplomi-insinöörejä tai vastaavan yliopistokoulutuksen saaneita henkilöitä. Jäsenistöstä poimittiin satunnaisotannalla 3000 työssä olevan henkilön edustava otos ja heistä 2897 toimitettiin kysely. Suomen Ekonomeihin kuuluu 50000 kauppatieteellisen yliopistotutkinnon suorittanutta henkilöä, joista poimittiin 3000 työssä olevan henkilön satunnaisotos ja heistä 2820:1le toimitettiin kysely.

Kaikki kyselyt toimitettiin tutkittaville sähköpostitse ammattiliittojen kautta. Kyselyn saatteena oli tutkijoiden laatima tiedote, joka sisälsi kuvauksen tutkimuksen toteuttajasta yhteystietoineen, tutkimuksen tarkoituksesta, sen yhteistyökumppaneista ja luottamuksellisuudesta. Kyselyyn saadut vastaukset palautuivat suoraan Jyväskylän yliopistolle yksinomaan tutkijoiden käyttöön. Professoriliitosta vastaajia oli 568 (45\%), Tieteentekijöiden liitosta 773 (26\%), Suomen Ekonomeista 486 (17\%) ja Tekniikan Akateemisista 373 (13\%).

Tähän tutkimukseen valittiin ne vastanneet henkilöt, jotka eivät tutkimushetkellä toimineet johtotehtävissä $(n=1151)$. Tutkittavista Professoriliiton jäseniä oli 104 (9\%), Tieteen- tekijöiden liiton jäseniä 582 (50\%), Suomen Ekonomien jäseniä oli 237 (21\%) ja Tekniikan Akateemisten jäseniä 228 (20\%). Tutkittavista 56 prosenttia oli naisia ja tutkittavien keski-ikä oli 45.6 vuotta $(k h=10.9$, vaihteluväli $25-72)$. Parisuhteessa oli 77 prosenttia tutkittavista ja 38 prosentilla oli alle 17-vuotiaita lapsia. Tieteentekijöiltä ja professoreilta kysyttiin tieteenalaa, joita tutkittavat edustivat laajasti, suurimpien alojen ollessa humanistinen, luonnontieteellinen ja yhteiskuntatieteellinen. Tekniikan Akateemisilta ja Suomen Ekonomeilta kysyttiin toimialaa, joita tutkittavat edustivat laajasti: eniten edustettuja toimialoja olivat teollisuus, energiaala ja rakentaminen, tietoliikenne ja tietojenkäsittelypalvelut sekä palvelut liike-elämälle.

\section{Kyselymenetelmät}

Johtotehtäviin liittyviä huolenaiheita mitattiin Worries about Leadership -kyselyllä (Aycan \& Shelia 2018), jossa tutkittavat arvioivat viisiportaisella asteikolla ( $1=$ hyvin vähän, $5=$ hyvin paljon) kuinka paljon tiettyjen johtotehtäviin liittyvien seikkojen mahdollisuus huolestuttaisi heitä, mikäli heille tarjoutuisi tilaisuus siirtyä johtotehtäviin. Kysely koostui yhteensä 16 väittämästä, joista viisi mittasi huolta epäonnistumisesta (esim. "Tekemäni virheet saavat enemmän huomiota") $(k a=2.35, k h=.88$, Cronbachin alfa .88), kuusi huolta työn ja muun elämän epätasapainosta (esim. "Minulla ei ole riittävästi aikaa ystävilleni") $(k a=2.74, k h=0.93$, Cronbachin alfa .87) ja viisi huolta vaikeuksista (esim. "Kohtelen työntekijöitä epäoikeudenmukaisesti") $(k a=2.12, k h=0.71$, Cronbachin alfa .70).

Johtotehtäviin liittyviä urasuunnitelmia tutkittiin kahdella kysymyksellä, joissa tutkittavat arvioivat viisiportaisella asteikolla $(1=$ hyvin epätodennäköistä, 5 = hyvin todennäköistä) kuinka todennäköisenä he pitävät pyrkimistään johtotehtäviin seuraavan viiden vuoden aikana a) nykyisessä organisaatiossaan $(k a=2.18$, $k h=1.15)$ ja b) jossakin toisessa organisaatiossa $(k h=2.40, k h=1.22)$.

Henkilökohtaisia työtavoitteita tutkittiin avoimella kysymyksellä, jossa tutkittavaa pyydettiin kirjoittamaan tärkein omaan työhön tai uraan liittyvä tavoite. Kysymys perustuu Littlen (1989) henkilökohtaisten projektien analyy- 
siin (Personal Project Analysis, PPA). Henkilökohtaisia työtavoitteita kartoittavan avoimen kysymyksen vastaukset luokiteltiin niiden sisällön perusteella aiemman tutkimustiedon (Huhtala ym. 2013; Hyvönen ym. 2009) pohjalta muodostettuihin luokkiin, jotka olivat ammatillinen osaaminen, uralla eteneminen, työhyvinvointi, työn vaihto, työn jatkuvuus, organisaation menestyminen, palkkakehitys, arvostus ja vaikuttaminen sekä työuran päättäminen. Uusia työtavoiteluokkia ei tässä aineistossa havaittu. Luokittelu suoritettiin kahdessa vaiheessa siten, että ensimmäisessä vaiheessa kaksi tutkijaa luokitteli vastaukset itsenäisesti. Toisessa vaiheessa kahden tutkijan luokittelujen yhdenmukaisuutta verrattiin ristiintaulukoinnin avulla. Ristiintaulukoinnin perusteella 69 \% vastauksista oli luokiteltu samaan luokkaan (kappa-arvo .69). Eri tavoin luokitelluissa tapauksissa luokitteluja verrattiin vielä kolmannen tutkijan tekemään luokitteluun, jonka jälkeen tutkijat yhteisesti päättivät vastausten sijoittamisesta luokkiin.

Taustamuuttujina tutkimuksessamme kontrolloitiin tutkittavien sukupuoli $(1=$ nainen, $2=$ mies), ikä (jatkuva muuttuja), ammattiliitto $(0=$ ei kuulu kyseiseen liittoon, 1 = kuuluu kyseiseen liittoon), onko tutkittava toiminut aiemmin johtotehtävissä ( $1=\mathrm{ei}, 2=$ kyllä), työsuhteen määräaikaisuus $(1=$ toistaiseksi voimassa oleva, 2 = määräaikainen), parisuhde ( 1 = kyllä, $2=$ ei) ja onko tutkittavalla alle 17-vuotiaita lapsia $(0=$ ei, $1=$ kyllä $)$.

\section{TULOKSET}

\section{Muuttujien kuvailevat tulokset}

Strukturoituihin kysymyksiin perustuvien muuttujien (johtotehtäviin liittyvät huolenaiheet, johtotehtäviin liittyvät urasuunnitelmat) sekä taustamuuttujien keskinäiset korrelaatiot on raportoitu Taulukossa 1. Korrelaatiotarkastelut osoittivat, että johtotehtäviin liittyvien huolenaiheiden kolme ulottuvuutta (huoli epäonnistumisesta, epätasapainosta sekä vaikeuksista ja ongelmista) olivat negatiivisesti yhteydessä johtotehtäviin hakeutumiseen toisessa organisaatiossa, mutta ei omassa organisaatiossa. Tutkittavien taustatekijöillä oli yhteyttä johtotehtäviin liittyviin huolenaiheisiin ja urasuunnitel- miin. Miehet raportoivat vähemmän huolia epäonnistumisesta ja työn ja muun elämän epätasapainosta. Lisäksi mitä vanhemmista tutkittavista oli kyse, sitä vähemmän he raportoivat kaikkia johtotehtäviin liittyviä huolenaiheita ja sitä vähemmän johtotehtäviin hakeutumisen urasuunnitelmia sekä omassa että toisessa organisaatiossa heillä oli. Ne tutkittavat, jotka eivät olleet parisuhteessa, raportoivat vähemmän huolta epätasapainosta työn ja muun elämän välillä ja ne, joilla oli alle 17-vuotiaita lapsia, raportoivat enemmän huolia epätasapainosta. Lisäksi ammattitausta oli yhteydessä johtotehtäviin liittyviin huoliin: professorit raportoivat vähemmän huolta epäonnistumisesta ja tieteentekijät enemmän.

Henkilökohtaisia työtavoitteita kartoittavaan avoimeen kysymykseen vastasi 875 tutkittavaa. Taulukossa 2 on nähtävissä työtavoitteiden sisältöjen luokitteluprosessin lopulliset luokat ja tutkittujen jakautuminen luokkiin. Tutkittujen kuvaamista henkilökohtaisista työtavoitteista oli tunnistettavissa kaikki Huhtalan ym. (2013) tutkimuksessa esiin nousseet yhdeksän työtavoiteluokkaa, joista suurimmat olivat pätevyys (38.3\% mainitsi tärkeimpänä tavoitteenaan), hyvinvointi (16.8\%), työn varmuus (10.6\%), urakehitys (7.5\%), työn vaihto (7.5\%), arvostus ja vaikuttaminen $(7 \%)$ ja organisaation menestys $(6.4 \%)$. Pienimmät luokat olivat työn lopettamiseen $(3.1 \%)$ ja rahaan (1\%) liittyvät tavoitteet. Tutkittujen vastauksissa oli myös pieni määrä (1.9\%) tavoitteita, jotka eivät kuvanneet työhön liittyviä tavoitteita (esimerkiksi perheen perustaminen) ja ne jätettiin siksi jatkoanalyysien ulkopuolelle.

\section{Johtotehtäviin liittyvien huolenaiheiden yhteys urasuunnitelmiin}

Johtotehtäviin liittyviin urasuunnitelmiin koskeviin kysymyksiin (2 osiota) vastasi 998 tutkittavaa. Yhdistimme nämä kaksi muuttujaa yhdeksi muuttujaksi, sillä alkuperäisten muuttujien jakaumat olivat hyvin vinoja ja yhdistetyllä, uudelleen luokitellulla muuttujalla saatiin tarkempaa tietoa tutkittujen johtotehtäviin liittyvistä urasuunnitelmista. Uuteen muuttujaan muodostettiin neljä luokkaa seuraavasti: 1 = tutkittavat, jotka todennäköisesti eivät pyri johtotehtäviin omassa eivätkä toisessa organi- 


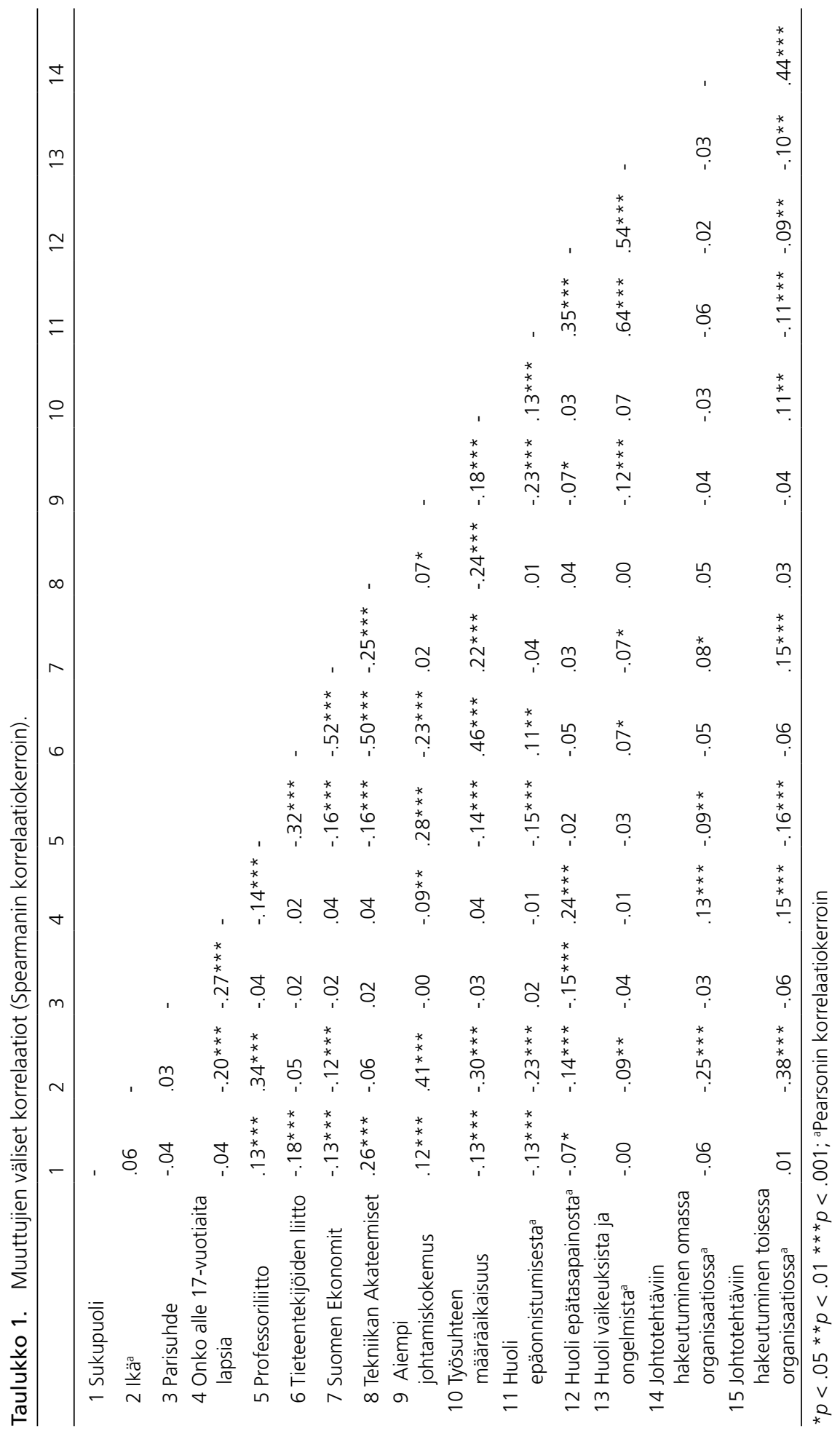


Taulukko 2. Henkilökohtaisten työtavoitteiden luokat ja jakaumat (tutkittavat maininneet tärkeimmän tavoitteensa).

\begin{tabular}{|c|c|c|c|}
\hline $\begin{array}{l}\text { Henkilökohtaisten } \\
\text { työtavoitteiden luokat }\end{array}$ & $\begin{array}{l}\text { Työtavoitteiden } \\
\text { määrät } \\
\%(n)\end{array}$ & Luokan sisällön kuvaus & $\begin{array}{l}\text { Esimerkkejä henkilökohtaisista } \\
\text { työtavoitteista }\end{array}$ \\
\hline 1. Pätevyys & $38.3(335)$ & $\begin{array}{l}\text { Hyvä työnteko, työssä } \\
\text { kehittyminen, oman osaamisen } \\
\text { kehittäminen }\end{array}$ & $\begin{array}{l}\text { "Osaamisen kehittäminen ja } \\
\text { ylläpitäminen", "Työn tekeminen } \\
\text { hyvin" }\end{array}$ \\
\hline 2. Urakehitys & $7.5(66)$ & $\begin{array}{l}\text { Korkeamman aseman } \\
\text { saavuttaminen, ylennys }\end{array}$ & $\begin{array}{l}\text { "Kehittyä ja päästä uralla } \\
\text { eteenpäin", "Johtotehtävä" }\end{array}$ \\
\hline 3. Hyvinvointi & $16.8(147)$ & $\begin{array}{l}\text { Tasapaino työn ja muun elämän } \\
\text { välillä, terveys, työkuormituksen } \\
\text { hallinta, motivaatio, työssä } \\
\text { viihtyminen }\end{array}$ & $\begin{array}{l}\text { "Tällä hetkellä tärkein tavoite } \\
\text { on pysyä hengissä", "Pitää työ } \\
\text { mielenkiintoisena", "Löytää } \\
\text { tasapaino työn ja vapaa-ajan } \\
\text { välillä" }\end{array}$ \\
\hline 4. Työn vaihto & $7.3(64)$ & $\begin{array}{l}\text { Työpaikan tai -tehtävän vaihto, } \\
\text { oman yrityksen perustaminen, } \\
\text { uran jatkaminen ulkomailla }\end{array}$ & $\begin{array}{l}\text { "Pidempi } \\
\text { ulkomaantyöskentelyjakso", } \\
\text { "Löytää itselle sopiva ja } \\
\text { mielenkiintoinen ala" }\end{array}$ \\
\hline 5. Organisaatio & $6.4(56)$ & $\begin{array}{l}\text { Organisaation tai tiimin } \\
\text { toiminnan edistäminen tai } \\
\text { menestys, käytännön tehtävät }\end{array}$ & $\begin{array}{l}\text { "Projektirahoituksen saaminen", } \\
\text { "Yhtiön arvon kasvattaminen" }\end{array}$ \\
\hline 6. Työn varmuus & $10.6(93)$ & $\begin{array}{l}\text { Pysyvä työsopimus, työn } \\
\text { jatkuminen, työn löytäminen, } \\
\text { aseman vakiinnuttaminen, } \\
\text { säännöllinen toimeentulo }\end{array}$ & $\begin{array}{l}\text { "Työpaikan löytäminen", } \\
\text { "Nykyisen vastuutason } \\
\text { säilyttäminen", "Pysyä } \\
\text { työelämässä eläkeikään asti" }\end{array}$ \\
\hline 7. Raha & $1.0(9)$ & $\begin{array}{l}\text { Palkankorotus, palkka itsessään, } \\
\text { muut rahalliset etuudet }\end{array}$ & $\begin{array}{l}\text { "Palkka ylös", "Perheen } \\
\text { elättäminen", "Vakaa } \\
\text { toimeentulo" }\end{array}$ \\
\hline 8. Työn lopettaminen & $3.1(27)$ & $\begin{array}{l}\text { Työuran lopettaminen, } \\
\text { eläköityminen, näihin tähtäävät } \\
\text { toimet, eläkkeelle siirtymisen } \\
\text { jälkeisen uran suunnittelu }\end{array}$ & $\begin{array}{l}\text { "Päästä hyvin mielin eläkkeelle", } \\
\text { "Kunnialla loppuun saakka", } \\
\text { "Saada tehdä työtä vielä } \\
\text { eläkeiän saavuttamisen jälkeen" }\end{array}$ \\
\hline $\begin{array}{l}\text { 9. Arvostus ja } \\
\text { vaikuttaminen }\end{array}$ & $7.0(61)$ & $\begin{array}{l}\text { Työn merkityksellisyys } \\
\text { työpaikan ulkopuolella, työstä } \\
\text { saatu arvostus, yleisen hyvän } \\
\text { edistäminen, tieteenalan } \\
\text { kehittäminen }\end{array}$ & $\begin{array}{l}\text { "Tehdä asioita, joilla on pysyvä } \\
\text { vaikutus yhteisöön", "Haluaisin } \\
\text { olla vaikuttamassa turvalliseen } \\
\text { tulevaisuuteen tuleville } \\
\text { sukupolville" }\end{array}$ \\
\hline 10. Muut & $1.9(17)$ & $\begin{array}{l}\text { Luokittelun ulkopuolelle jäävät } \\
\text { vastaukset }\end{array}$ & $\begin{array}{l}\text { "Ei tavoitteita", "Perheen } \\
\text { perustaminen" }\end{array}$ \\
\hline Yhteensä & 100 (875) & & \\
\hline
\end{tabular}


saatiossa, 2 = tutkittavat, jotka todennäköisesti pyrkivät johtotehtäviin toisessa mutta eivät omassa organisaatiossa, 3 = tutkittavat, jotka todennäköisesti pyrkivät johtotehtäviin omassa mutta eivät toisessa organisaatiossa, $4=$ tutkittavat, jotka todennäköisesti pyrkivät johtotehtäviin omassa ja toisessa organisaatiossa. Tutkittavat, jotka olivat vastanneet kysymykseen "melko todennäköisesti" tai "erittäin todennäköisesti" luokiteltiin kuuluvan niihin, jotka todennäköisesti pyrkivät johtotehtäviin. Tutkittavat, jotka olivat vastanneet "erittäin epätodennäköisesti", "melko epätodennäköisesti" tai "siltä väliltä", luokiteltiin niihin, jotka eivät aio pyrkiä johtotehtäviin. Tutkittavista selkeä enemmistö (70,5 prosenttia) ei suunnitellut hakeutuvansa johtotehtäviin omassa eikä toisessa organisaatiossa (luokka 1). Sen sijaan 12,7 prosenttia suunnitteli hakeutuvansa johtotehtäviin toisessa mutta ei omassa organisaatiossa (luokka 2), 8,6 prosenttia suunnitteli hakeutuvansa johtotehtäviin omassa mutta ei toisessa organisaatiossa (luokka 3) ja 4,7 suunnitteli hakeutuvansa johtotehtäviin sekä omassa että toisessa organisaatiossa (luokka 4).
Vertailimme johtotehtäviin liittyviä huolenaiheita edellä kuvatuissa urasuunnitelmaluokissa kovarianssianalyysin avulla käyttäen IBM SPSS Statistics 24 -ohjelmaa. Analyyseissä kontrolloitiin ne taustamuuttujat, jotka korrelaatioiden perusteella olivat vähintään melkein merkitsevästi $(p \leq 0.05)$ yhteydessä johtotehtäviin liittyviin huolenaiheisiin (ks. Taulukko 1). Kuten Taulukosta 3 käy ilmi, eniten kaikkia johtotehtäviin liittyviä huolenaiheita kokivat ne tutkittavat, jotka eivät suunnitelleet lainkaan pyrkivänsä johtotehtäviin. Heidän huolenaiheidensa keskiarvot olivat merkitsevästi korkeampia kuin niiden tutkittavien, jotka suunnittelivat pyrkivänsä johtotehtäviin toisessa organisaatiossa. Lisäksi ne tutkittavat, jotka eivät suunnitelleet pyrkivänsä johtotehtäviin, raportoivat merkitsevästi enemmän huolta epäonnistumisesta verrattuna niihin, jotka halusivat pyrkiä johtotehtäviin joko omassa tai toisessa organisaatiossa. Ensimmäinen hypoteesimme sai siis tukea: tutkittavien johtotehtäviin liittyvät huolenaiheet ovat yhteydessä siihen, että johtotehtäviin liittyviä urasuunnitelmia on vähemmän.

Taulukko 3. Johtotehtäviin pyrkimiseen liittyvät urasuunnitelmat ja johtotehtäviin liittyvät huolenaiheet (kovarianssianalyysi).

\begin{tabular}{|c|c|c|c|c|c|c|c|}
\hline & $\begin{array}{l}\text { 1. Ei pyri } \\
\text { johtotehtäviin } \\
\begin{array}{l}(n=704) \\
k a(k h)\end{array}\end{array}$ & $\begin{array}{l}\text { 2. Pyrkii } \\
\text { johtotehtäviin } \\
\text { vain toisessa } \\
\text { organisaatiossa } \\
(n=127) \\
k a(k h)\end{array}$ & $\begin{array}{l}\text { 3. Pyrkii } \\
\text { johtotehtäviin } \\
\text { vain omassa } \\
\text { organisaatiossa } \\
(n=86) \\
k a(k h)\end{array}$ & $\begin{array}{l}\text { 4. Pyrkii } \\
\text { johtotehtäviin } \\
\text { omassa ja } \\
\text { toisessa } \\
\text { organisaatiossa } \\
(n=81) \\
k a(k h)\end{array}$ & F-testi & $\begin{array}{l}\text { Pari- } \\
\text { vertailut }\end{array}$ & $\eta^{2}$ \\
\hline $\begin{array}{l}\text { Huoli } \\
\text { epäonnistumisesta }\end{array}$ & $2.38(.88)$ & $2.23(.84)$ & $2.38(.81)$ & $2.15(.85)$ & $6.29 * * *$ & $1>2,4$ & .021 \\
\hline $\begin{array}{l}\text { Huoli } \\
\text { epätasapainostab }\end{array}$ & $2.78(.94)$ & $2.58(.86)$ & $2.66(.90)$ & $2.70(.92)$ & $5.74 * *$ & $1>2$ & .018 \\
\hline $\begin{array}{l}\text { Huoli vaikeuksista } \\
\text { ja ongelmistac }\end{array}$ & $2.15(.70)$ & $1.97(.72)$ & $2.06(.64)$ & $2.21(.81)$ & $3.21 *$ & $1>2$ & .010 \\
\hline
\end{tabular}

${ }^{*} p<.05 * * p<.01 * * * p<.001$

$1=$ Bonferroni-vertailu

a kontrolloitu sukupuoli, ikä, ammattiliitto, aiempi kokemus johtotehtävistä ja työsuhteen määräaikaisuus

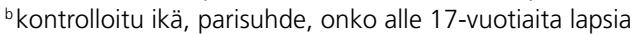

ckontrolloitu ikä ja aiempi kokemus johtotehtävistä 


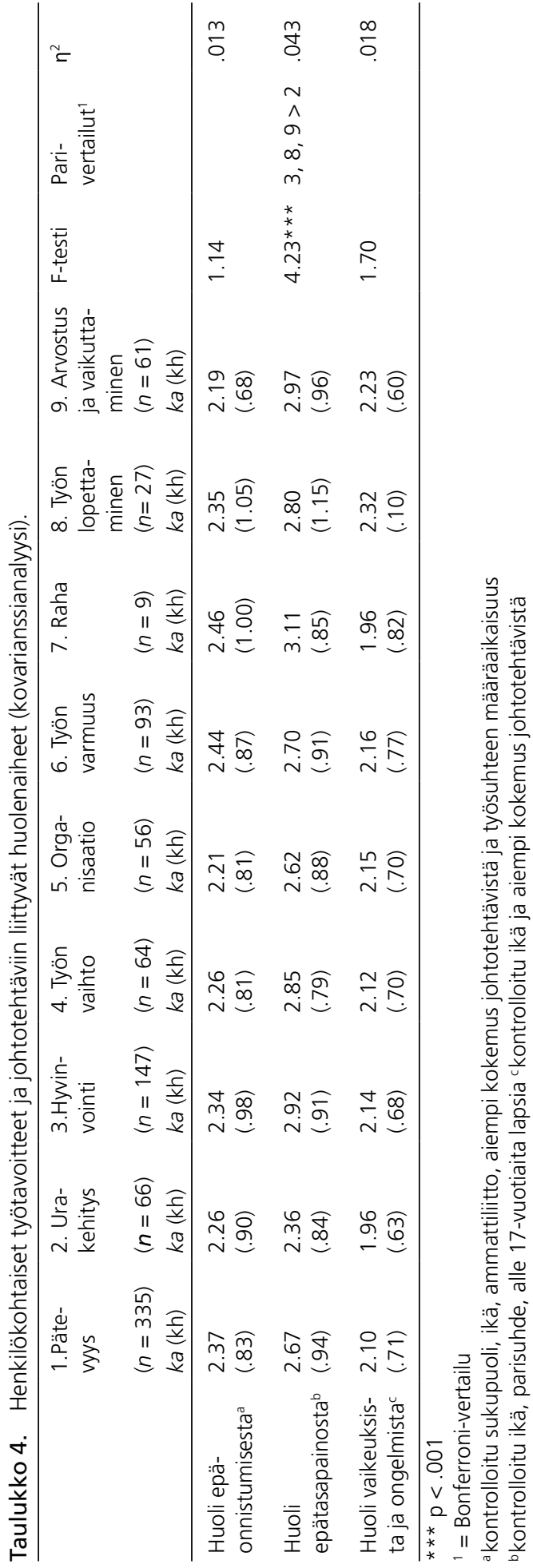

\section{Johtotehtäviin liittyvien huolenaiheiden yhteys henkilökohtaisiin työtavoitteisiin}

Johtotehtäviin liittyviin huolenaiheiden yhteyksiä tutkittujen asiantuntijoiden tärkeimpään henkilökohtaiseen työtavoitteiseen analysoitiin kovarianssianalyysin avulla (Taulukko 4). Analyysissa kontrolloitiin ne taustatekijät, jotka korrelaatioiden perusteella olivat vähintään melkein merkitsevästi yhteydessä johtotehtäviin liittyviin huolenaiheisiin. Toisen hypoteesimme mukaisesti tulokset osoittivat, että vähiten huolta työn ja muun elämän epätasapainosta johtotehtäviin liittyen kokivat ne tutkittavat, joiden tärkein henkilökohtainen työtavoite oli oma urakehitys. Lisäksi tulokset osoittivat, että johtotehtävään liittyvät huolet työn ja muun elämän epätasapainosta erosivat merkitsevästi työtavoiteluokkien välillä. Eniten huolta työn ja muun elämän epätasapainosta johtotehtävissä kokivat ne asiantuntijat, joiden tärkein työtavoite liittyi hyvinvointiin, työn lopettamiseen tai arvostukseen ja vaikuttamiseen. Johtotehtäviin liittyvät huolet, jotka koskivat epäonnistumista tai vaikeuksia ja ongelmia eivät eronneet eri työtavoiteluokkien välillä.

\section{POHDINTA}

Tutkimuksemme päätavoitteena oli selvittää, ovatko johtotehtäviin liittyvät huolenaiheet yhteydessä johtotehtäviin liittyviin urasuunnitelmiin ja henkilökohtaisiin työtavoitteisiin korkeasti koulutetuilla asiantuntijoilla. Tutkitut asiantuntijat olivat professoreita, tieteentekijöitä, eri aloilla työskenteleviä ekonomeja ja tekniikan alan korkeakoulutettuja ammattilaisia. Tutkittavat eivät tutkimushetkellä työskennelleet johtotehtävissä.

\section{Johtotehtäviin liittyvät huolenaiheet kytkeytyvät haluttomuuteen pyrkiä johtotehtäviin}

Runsas kaksi kolmasosaa (70,5 \%) tutkituista asiantuntijoista ei suunnitellut hakeutuvansa johtotehtäviin lainkaan. Johtotehtäviin haluttomien osuus tutkimuksessamme oli samaa suuruusluokkaa kuin Torresin (2014) tutkimuksessa, joskin täytyy muistaa, että tutkimusten kohdejoukot eivät ole täysin vertailukelpoiset (tässä 
tutkimuksessa yliopistotyöntekijöitä oli yli puolet osallistujista). Tulosten perusteella hakeutuminen johtotehtäviin toisessa organisaatiossa oli suositumpaa verrattuna johtotehtäviin hakeutumiseen omassa organisaatiossa, sillä tutkittavista 12.7 prosenttia suunnitteli hakeutuvansa johtotehtäviin vain toisessa ja 8,6 prosenttia vain omassa organisaatiossa. Vain pieni osa tutkittavista $(4,7 \%)$ suunnitteli hakeutuvansa johtotehtäviin sekä omassa että toisessa organisaatiossa. Johtotehtäviä organisaatiosta riippumatta tavoittelevien osuus $(10,7 \%)$ on saman suuruinen kuin parempaan asemaan etenemistä tärkeänä pitävien palkansaajien osuus, sillä vain noin joka kymmenes palkansaaja piti uralla etenemistä erittäin tärkeänä työolotutkimuksessa (Lehto \& Sutela 2014). Työ- ja elinkeinoministeriön työolobarometrin (Lyly-Yrjänäinen 2018) mukaan palkansaajat kokevat yleisen työllisyystilanteen myönteisemmäksi kuin oman työpaikan taloudellisen tilanteen. Tämän vuoksi tutkittavat saattavat kokea johtotehtävät houkuttelevammaksi oman organisaationsa ulkopuolella.

Ensimmäisen hypoteesimme (H1) mukaisesti havaitsimme, että niillä asiantuntijoilla, joilla oli enemmän johtotehtäviin liittyviä huolenaiheita, oli vähemmän johtotehtäviin liittyviä urasuunnitelmia. Asiantuntijat, jotka eivät suunnitelleet pyrkivänsä lainkaan johtotehtäviin, olivat enemmän huolissaan mahdollisesta epäonnistumisesta, työn ja muun elämän epätasapainosta sekä vaikeuksista johtotehtävien seurauksiin liittyen verrattuna niihin asiantuntijoihin, jotka suunnittelivat pyrkivänsä johtotehtäviin jossain toisessa organisaatiossa. Teoreettisen mallimme (Aycan \& Shelia 2018) valossa tulos voi selittyä sillä, että asiantuntijat, joilla on runsaasti johtotehtäviin liittyviä huolia, kokevat johtotehtävät uhkana perustarpeidensa täyttymiselle (autonomia, kompetenssi ja yhteenkuuluvuus; Deci \& Ryan 1985). Välttääkseen nämä uhat asiantuntijat voivat noudattaa itseä vahingoittavaa strategiaa (Jones \& Berglas 1978) eivätkä siten suunnittele hakeutuvansa johtotehtäviin.

Mielenkiintoinen havainto oli, että tutkittujen asiantuntijoiden huolet epäonnistumisesta, työn ja muun elämän epätasapainosta sekä vaikeuksista ja ongelmista olivat merkityksellisiä suunniteltaessa johtotehtäviin hakeutumista toiseen organisaatioon, mutta eivät niinkään omassa organisaatiossa. On mahdollista, että asiantun- tijoiden pohtiessa johtotehtäviin hakeutumista omassa organisaatiossaan, organisaatio käytänteineen ja toimintatapoineen on heille niin tuttu, ettei mahdollisia johtotehtäviä koeta voimakkaana uhkana (Lazarus 1991) eivätkä huolenaiheet siten aiheuta uhkaa perustarpeiden täyttymiselle (Deci \& Ryan 1985). Lisäksi tutussa toimintaympäristössä johtamista tukevat voimavarat ja johtamisen tukirakenteet (esim. esimiesten työnohjaus) ovat paremmin tiedossa, minkä vuoksi johtotehtäviin liittyvät huolenaiheet eivät aiheuta samassa määrin välttelyä kuin harkittaessa johtotehtäviä toisessa organisaatiossa.

\section{Huoli työn ja muun elämän epätasapai- nosta johtotehtävissä on yhteydessä henkilökohtaisiin työtavoitteisiin}

Tuloksemme tukivat osittain toista oletustamme (H2). Kolmesta tutkitusta johtotehtäviin liittyvästä huolenaiheesta huoli epätasapainosta työn ja muun elämän välillä oli yhteydessä tutkittujen asiantuntijoiden kuvaamiin henkilökohtaisiin työtavoitteisiin, jotka liittyivät urakehitykseen. Asiantuntijat, jotka raportoivat vähiten huolta työn ja muun elämän epätasapainosta liittyen mahdollisiin johtotehtävien seurauksiin, asettivat muita useammin tärkeimmäksi henkilökohtaiseksi työtavoitteekseen urakehityksen (esim. ylennyksen, korkeamman aseman, johtotehtävän). Kaikkiaan urakehityksen nosti tärkeimmäksi tavoitteekseen 7,5 prosenttia tutkituista. Perinteisesti perheen perustaminen ja uralla eteneminen on voitu nähdä jopa toisensa poissulkevina tulevaisuuden tavoitteina. Voikin olla, että vähiten huolta työn ja muun elämän epätasapainosta raportoivat asiantuntijat kokevat urakehityksen tärkeämpänä tavoitteena kuin perheeseen ja omaan vapaa-aikaan liittyvät asiat. Toisaalta voi olla, että urakehitystä tavoittelevilla asiantuntijoilla on hyvät psyykkiset hallintakeinot työn ja muun elämän tasapainottamiseen ja siksi huolta työn ja muun elämän epätasapainosta ei koeta voimakkaana.

Oletuksemme ulkopuolelta havaitsimme, että johtotehtäviin liittyvät huolet työn ja muun elämän epätasapainosta kytkeytyivät henkilökohtaisiin tavoitteisiin, joissa korostui hyvinvointi (esim. työkuormituksen hallinta, motivaatio, työssä viihtyminen). Kaikkiaan hyvinvointiin 
liittyvän tavoitteen nosti keskeisimmäksi kuudesosa (16,8 \%) asiantuntijoista, joka on samaa luokkaa kuin Huhtalan ym. (2013) suomalaisiin teknisen ja kaupallisen alan johtajien tutkimuksessa (12\%) ja Hyvösen ym. (2009) nuorten esimiesten tutkimuksessa (15\%). On mahdollista, että hyvinvoinnin tavoitteita priorisoivat asiantuntijat arvioivat johtotehtävien seuraukset herkemmin työn ja muun elämän tasapainoa uhkaaviksi, koska hyvinvoinnin ylläpitämiseen liittyy $\mathrm{mm}$. kuormituksen hallinta työssä ja työkuormituksesta palautuminen vapaa-ajalla (esim. henkinen työstä irrottautuminen) (Kinnunen 2017). Toisaalta on mahdollista, että hyvinvoinnin tavoitteet liittyvät jo olemassa oleviin hyvinvoinnin ja työssä jaksamisen ongelmiin - kuten Hyvösen ym. (2009) tutkimuksessa on havaittu - minkä vuoksi asiantuntijat ovat huolissaan johtotehtävien kielteisistä seurauksista työn ja muun elämän tasapainolle.

Korkeasti koulutettujen asiantuntijoiden johtotehtäviin liittyvät huolet työn ja muun elämän epätasapainosta kytkeytyivät myös heidän henkilökohtaisiin työtavoitteisiinsa, jotka liittyivät arvostukseen ja vaikuttamiseen (esim. yleisen hyvän edistäminen, työn merkityksellisyys yhteiskunnassa). Arvostukseen ja vaikuttamiseen liittyviä tavoitteita raportoi kaikkiaan seitsemän prosenttia tutkituista asiantuntijoista, mikä on hieman enemmän kuin Huhtalan ym. (2013) teknisen ja kaupallisen alan johtajien tutkimuksessa (4\%). Voi olla, että asiantuntijoilla, jotka tavoittelevat työssään laajempaa yhteiskunnallista vaikuttamista/arvostusta, työ vie jo nykyisellään paljon aikaa perheeltä ja muulta elämältä. He saattavat siis nähdä johtotehtävät ylimääräisenä velvollisuutena, joka rajoittaa autonomian tarvetta (Aycan \& Shelia 2018), eikä vie kohti tavoitetta yhteiskunnallisesta vaikuttamisesta. Tässä yhteydessä on syytä muistaa, että tutkittujen joukossa oli huomattavan suuri määrä tiedeyhteisön asiantuntijoita (professoreita $9 \%$, tieteentekijöitä $51 \%$ ), jotka saattavat kokea esimerkiksi hallinnollisten johtotehtävien uhkaavan oman tutkimusalan edistämistä ja näin ollen myös yhteiskunnallista vaikuttamista, mikä on keskeinen ja arvostettu professoreiden ja tieteentekijöiden työnkuvaa määrittävä tehtävä.

Huolet työn ja muun elämän epätasapainosta kytkeytyivät myös henkilökohtaisiin työtavoitteisiin, jotka liittyivät työn lopettamiseen. Työn lopettamista (työuran päättäminen, eläkkeelle siirtyminen) tavoitteli vain pieni osa tutkittavista (3\%), mutta yhteys johtotehtäviin liittyviin työn ja muun elämän epätasapainon huoliin oli kuitenkin merkitsevä. Tarkemmat tarkastelumme osoittivat, että työn lopettamista työtavoitteenaan priorisoivat henkilöt olivat vanhempia (keski-ikä 61 vuotta) verrattuna muihin tutkittaviin (keski-ikä 45 vuotta) ja näin ollen näitä tavoitteita kuvanneet asiantuntijat olivat lähempänä eläkesiirtymää. On ymmärrettävää, että eläkeiän lähestyessä asiantuntijat liittävät mahdollisiin johtotehtäviin herkemmin huolta työn ja muun elämän epätasapainosta (esim. huoli eläkesiirtymän sujuvuudesta mahdollisissa johtotehtävissä).

\section{Tutkimuksen arviointia ja johtopäätökset}

Tutkimuksemme vahvuus on laaja tutkimusaineisto, johon osallistui korkeasti koulutettuja asiantuntijoita sekä yliopistoista sekä kaupallisilta ja teknisiltä aloilta. Käyttämämme iso ja monipuolinen aineisto parantaa tulosten yleistettävyyttä. Tutkimuksemme vahvuutena on myös sen monimenetelmällinen asetelma, joka sisälsi sekä määrällisiä, strukturoituja kyselymenetelmiä (johtotehtävien huolenaiheet, urasuunnitelmat) että avoimen kysymyksen (henkilökohtaiset työtavoitteet), jonka vastaukset analysoitiin sisältölähtöisesti. Näin ilmiöstä saatiin monipuolisempi kuva kuin pelkästään valmiita vastausvaihtoehtoja käyttämällä.

Toisaalta on huomioitava, että havaintojemme laajempi yleistäminen muihin ammattiryhmiin (esim. opetushenkilöstö peruskouluissa ja keskiasteella, terveydenhuoltoalan ammattihenkilöstö) vaatii kuitenkin lisätutkimusta jatkossa. Lisäksi on syytä huomioida, että kustakin ammattiliitosta erikseen tarkasteltuna vastausprosentit jäivät joiltain osin melko alhaisiksi. Näin ollen emme voi tietää, miten vastaamatta jättäneet ovat saattaneet poiketa tutkittavan ilmiön, eli johtamisen huolenaiheiden suhteen vastanneista asiantuntijoista. Tulosten tulkintaa rajoittavana tekijänä voidaan pitää myös poikkileikkausasetelmaa, jonka vuoksi emme voineet osoittaa syy-seuraussuhteita johtotehtäviin liittyvien huolten yhteyksistä urasuunnitelmiin ja henkilökohtaisiin työtavoitteisiin. Pystymme ainoastaan toteamaan, että johtotehtäviin liittyvät 
huolet kytkeytyvät urasuunnitelmiin ja henkilökohtaisiin työtavoitteisiin. Jatkossa johtotehtäviin liittyvien huolenaiheiden yhteyttä urasuunnitelmiin ja henkilökohtaisiin työtavoitteisiin olisikin syytä tutkia samojen henkilöiden seurantatutkimuksella. Näin saataisiin tietoa siitä, hakeutuvatko runsaasti huolenaiheita kokevat asiantuntijat epätodennäköisemmin johtotehtäviin heidän toteutuneiden uravaiheidensa seuraamisen perusteella.

Johtopäätöksenä toteamme, että korkeasti koulutettujen asiantuntijoiden johtotehtäviin liittyvät huolenaiheet kytkeytyvät siihen, että johtotehtävät eivät kuulu heidän urasuunnitelmiinsa. Lisäksi johtotehtäviin liittyvät huolet työn ja muun elämän epätasapainosta kytkeytyvät asiantuntijoiden henkilökohtaisiin työtavoitteisiin, joilla tavoitellaan hyvinvointia, työn lopettamista sekä arvostusta ja vaikuttamista, mutta jotka eivät sisällä pyrkimistä oman uran kehittämiseen. Tulostemme perusteella johtotehtäviin liittyvien huolenaiheiden huomioiminen työpaikoilla - niin yliopistoissa kuin kaupallisen ja teknillisen alan organisaatioissakin - voi auttaa purkamaan esteitä johtotehtäviin pyrkimisen tai niiden vastaanottamisen tieltä (Aycan \& Shelia 2018). Johtotehtäviin liittyviä epäonnistumisen huolia tulisi lieventää tarjoamalla asiantuntijoille kouluttautumismahdollisuuksia ja tukiverkkoja (esim. säännölliset kehityskeskustelut ja valmennukset), joilla voidaan

\section{LÄHTEET}

Austin, James \& Vancouver, Jeffrey (1996). Goal constructs in psychology: Structure, process, and content. Psychological Bulletin, 120(3), 338-375.

Aycan, Zeynep \& Shelia, Salome (2018). "Leadership? No thanks!" A new construct: worries about leadership. European Management Review, 16(1), 21-35.

Chan, Kim Y. \& Drasgow, Fritz (2001). Toward a theory of individual differences and leadership: Understanding the motivation to lead. Journal of Applied Psychology, 86(3), 481-498.

Deci, Edward. L. \& Ryan, Richard M. (1985). Intrinsic motivation and self-determination in human behavior. New York: Plenum.

Deci, Edward L. \& Ryan, Richard M. (2000). The "what" and "why" of goal pursuits: Human needs and the self-determination of behavior. Psychological Inquiry, 11(4), 227-268. tukea tunnetta omasta kyvykkyydestä johtajana. Koulutuksen ja tuen merkitys korostuu erityisesti sellaisilla asiantuntijoilla, joille omaan koulutukseen ei ole sisältynyt johtamiseen liittyviä opintoja. Esimerkiksi yliopistoissa työskentelevien asiantuntijoiden (professorit, tieteentekijät) tutkintoihin liittyviin koulutuksiin ei välttämättä ole kuulunut missään vaiheessa lainkaan johtotehtäviin valmentavaa koulutusta.

Johtotehtäviin liittyvät huolenaiheet on syytä ottaa huomioon myös asiantuntijoiden urasuunnittelussa, sillä usein luontaisena urakehityksenä nähty eteneminen johtotehtäviin ei välttämättä ole kaikille asiantuntijoille puoleensa vetävä vaihtoehto. Johtotehtäviin liittyvät huolenaiheet ja niiden osoitetut yhteydet urasuunnitelmiin ja henkilökohtaisiin työtavoitteisiin tulisi huomioida esimerkiksi asiantuntijoita työllistävien yritysten HR-yksiköissä, joissa tarvittavalla valmennuksella ja organisatorisilla tukirakenteilla voidaan edesauttaa parhaimman potentiaalin omaavan henkilön päätymistä johtotehtäviin mahdollisista huolista huolimatta.

\section{KIITOKSET}

Tutkimus on osa Johtamisen pelko -projektia, jota on rahoittanut Työsuojelurahasto (hankenumero 116163).

Elliot, Andrew J. \& Church, Marcy A. (2003). A motivational analysis of defensive pessimism and self-handicapping. Journal of Personality, 71(3), 369-396.

Feldt, T., Tsupari, H., Kilponen, K., Auvinen, E., Huhtala, M., Muotka, J., \& Mauno, S. (2019). Miltä johtotehtävä tuntuisi? Johtotehtävien seurauksiin liittyvät huolenaiheet korkeasti koulutetuilla asiantuntijoilla, niiden selittäjät ja seuraukset. Jyväskylän yliopiston psykologian laitoksen julkaisuja, 356. Jyväskylä: Jyväskylän yliopisto, psykologian laitos. http://urn.fi/ URN:ISBN:978-951-39-7804-4

Forgas, Joseph P. (1995). Mood and judgement: The affect infusion model (AIM). Psychological Bulletin, 117(1), 39-66.

Greenhaus, Jeffrey H., Callanan, Gerard A. \& Kaplan, Eileen (1995). The role of goal setting 
in career management. International Journal of Career Management, 7(5), 3-12.

Haapakorpi, Arja (2008). Tohtorien varhaiset urat työmarkkinoilla ja tohtorikoulutuksen merkitys työelämässä. Aarresaari. Hermes.

Huhtala, Mari, Feldt, Taru, Hyvönen, Katariina \& Mauno, Saija (2013). Ethical organisational culture as a context for managers' personal work goals. Journal of Business Ethics, 114(2), 265-282.

Hyvönen, Katriina \& Feldt, Taru (2017). Henkilökohtaiset työtavoitteet ja hyvinvointi. Teoksessa Salmela-Aro, Katariina \& Nurmi Jari-Erik (toim.), Mikä meitä liikuttaa? Motivaatiopsykologian perusteet (s. 133-148). Jyväskylä: PSkustannus.

Hyvönen, Katriina, Feldt, Taru, Kinnunen, Ulla \& Tolvanen, Asko (2011). Changes in personal work goals in relation to the psychosocial work environment: A two-year follow-up study. Work \& Stress, 25(4), 289-308.

Hyvönen, Katriina, Feldt, Taru, Salmela-Aro, Katriina, Kinnunen, Ulla \& Mäkikangas, Anne (2009). Young managers' drive to thrive: A personal work goal approach to burnout and work engagement. Journal of Vocational Behavior, 75(2), 183-196.

Hyvönen, Katriina, Räikkönen, Eija, Feldt, Taru, Mauno, Saija, Dragano, Nico \& Matthewman, Lisa (2017). Long-term reward patterns contribute to personal goals at work among finnish managers. Journal of Career Development, 44(5), 394-408.

Jones, Edward E. \& Berglas, Steven (1978). Control of attributions about the self through self-handicapping strategies: The appeal of alcohol and the role of underachievement. Personality and Social Psychology Bulletin, 4(2), 200-206.

Kinnunen, Ulla (2017). Työstä palautuminen. Teoksessa Mäkikangas, Anne, Mauno, Saija \& Feldt, Taru (toim.). Tykkää työstä. Työhyvinvoinnin psykologiset perusteet (s. 127-147). Jyväskylä: PS-Kustannus.

Lappalainen, P. (2012). "Socially competent leadership - predictors, impacts and skilling in engineering." Väitöskirja, Lappeenrannan teknillinen yliopisto. Haettu sivulta https://lutpub. lut.fi/bitstream/handle/10024/74572/isbn $\% 20$ 9789522652089.pdf? sequence $=1$ \&isAllowed $=y$

Lazarus, R. S. (1991). Emotion and adaptation. New York: Oxford University Press.

Lent, Robert W. \& Brown, Steven D. (1996). Social cognitive approach to career development: An overview. The Career Development Quarterly, 44(4), 310-321.
Little, Brian R. (1989). Personal Project Analysis: Trivial Pursuits, Magnificent Obsessions and the Search for Coherence. Teoksessa Buss, David M., Cantor Nancy (toim) Personality Psychology: Recent Trends and Emerging Directions (s. 15-31). New York: Springer.

Little, Brian R. (2007). Prompt and Circumstance: The Generative Contexts of Personal Projects Analysis. Teoksessa Brian R. Little, Salmela-Aro Katariina \& Phillips, Susan D. (toim.), Personal Project Pursuit: Goals, action, and human flourishing (s. 3-49). Mahwah, New Jersey: Lawrence Erlbaum Associates.

Little, Brian R. (2011). Personal projects and motivational counseling: The quality of lives reconsidered. Teoksessa Cox W. Miles \& Klinger, Eric (toim.), Handbook of motivational counseling: Goal-based approaches to assessment and intervention with addiction and other problems (s. 73-88). Chichester, UK: Wiley

Lyly-Yrjänäinen, Maija (2018). Työolobarometri 2017 - Ennakkotiedot. Työ- ja elinkeinoministeriön julkaisuja 3/2018. Työ- ja elinkeinoministeriö. Haettu sivulta https://julkaisut.valtioneuvosto.fi/bitstream/handle/10024/160557/ TEMrap_3_2018_Tyoolobarometri.pdf?sequence=1\&isAllowed=y, 29.4.2018

McAdams, Dan (1995). What do we know when we know a person? Journal of Personality, 63, 365-396.

Nurkkala, R. 2018. Psykologiset sopimukset akateemisessa johtamisessa: Tapausesimerkkinä yliopistojen keskijohto. Akateeminen väitöskirja, Lapin yliopiston yhteiskuntatieteellinen tiedekunta. Rovaniemi: Lapin yliopistopaino.

Petäjäniemi, K. Viisi vuotta työelämässä - vuonna 2011 valmistuneiden kauppatieteiden maisterien tilanne syksyllä 2016. Suomen ekonomien julkaisu 3/2017.

Professoriliitto (2014). Professorin työ -selvitys: professorin esimiestehtävää koskeva osio. Työterveyslaitos.

Rojewski, Jay W. (2005) Occupational aspirations: Constructs, meanings and application. Teoksessa Brown, Steven D. \& Lent, Robert W. (toim.), Career Development and Counseling: Putting Theory and Research to Work (s. 131134). Hoboken: N.J.

Sainio, J. \& Carver, E. 2016. Tavoitteidensa mukaisella työuralla: Aarresaari verkoston tohtoriseuranta 2015, vuosina 2012-2013 valmistuneet.

Salmela-Aro, Katariina \& Nurmi, Jari-Erik (2017). Henkilökohtaiset tavoitteet, hyvinvointi ja elämänkulku. Teoksessa Salmela-Aro, Katariina \& Nurmi Jari-Erik (toim.), Mikä meitä liikuttaa? 
Motivaatiopsykologian perusteet (s. 133-148). Jyväskylä: PS-kustannus.

Sutela, Hanna \& Lehto, Anna-Maija (2014). Työolojen muutokset 1977-2013. Helsinki: Tilastokeskus.

Torres, Nicole (2014). Most people don't want to be managers. Harvard Business Review. Haettu sivulta https://hbr.org/2014/09/most-peopledont-want-to-be-managers, 1.5.2018.

Välimaa, Jussi, Stenvall, Jari, Siekkinen, Taru, Pekkola, Elias, Kivistö, Jussi, Kuoppala, Kari, Nokkala, Terhi, Aittola, Helena \& Ursin, Jani
(2016). Neliportaisen tutkijanturamallin arviointihankkeen loppuraportti. Opetus- ja kulttuuriministeriön julkaisuja.

Wiese, Bettina S., \& Salmela-Aro, Katariina (2008). Goal conflict and facilitation as predictors of work-family satisfaction and engagement. Journal of Vocational Behavior, 73(3), 490-497.

Zimmerman, Barry J., Bandura, Albert \& Martinez-Pons, Manuel (1992). Self-motivation for academic attainment: The role of self-efficacy beliefs and personal goal setting. American Educational Research Journal, 29(3), 663-67. 